
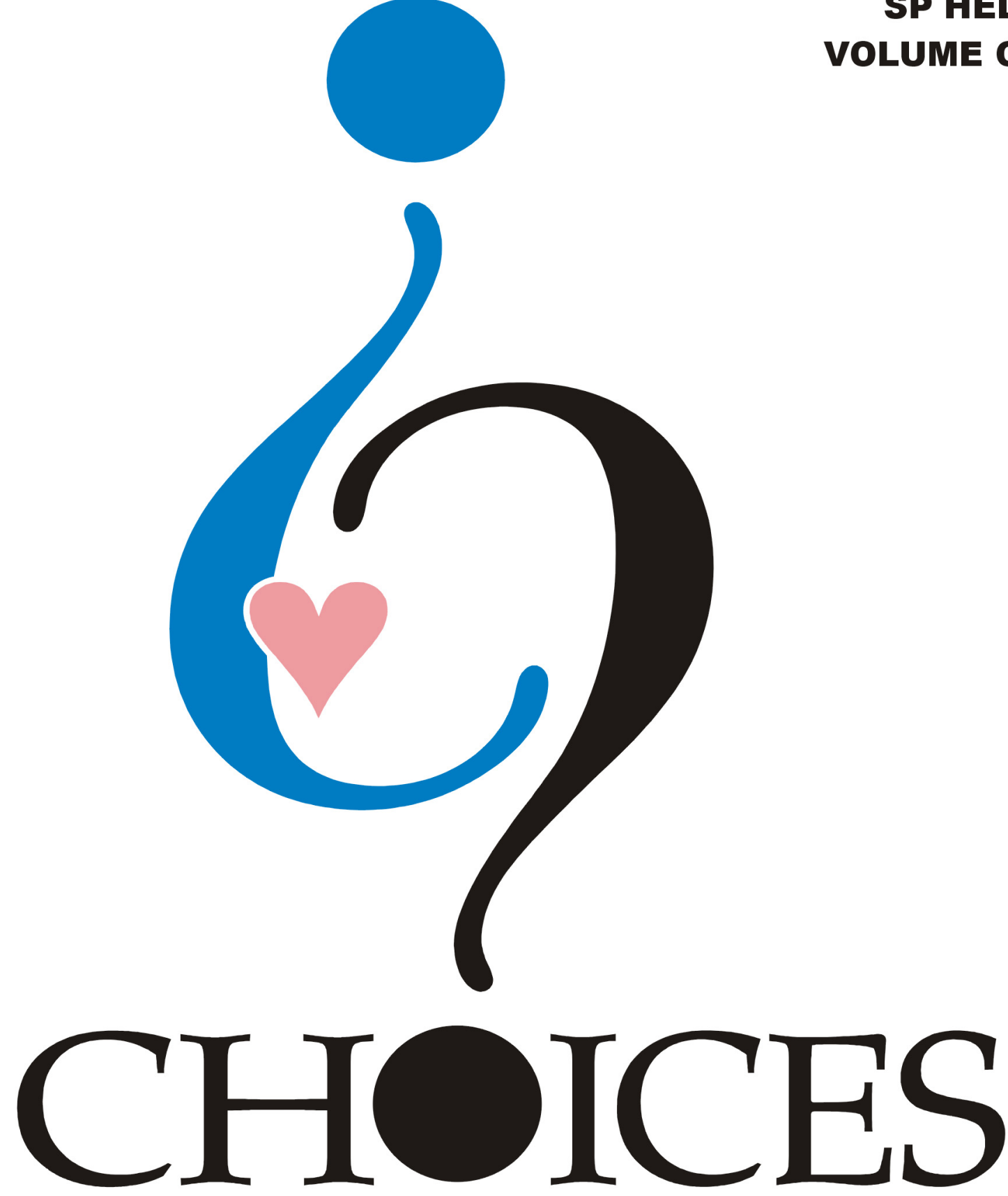

Charting A Positive Future For Teen Parents

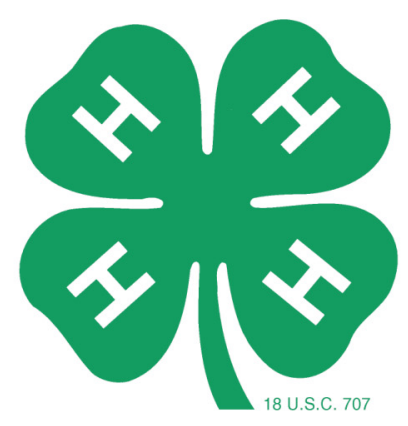




\section{CREDITS AND ACKNOWLEDGMENTS}

CHOICES, VOLUME II, was developed through a team effort of the Department of Home Economics including the Expanded Food and Nutrition Education Program and the Department of 4-H and Other Youth Programs.

Contributors to this curriculum are:

FOCUS on TEENS

\author{
M. Joy Cantrell-Jordan \\ Professor \\ Extension 4-H Youth Specialist
}

Maternal/Young Infant Nutrition

Linda B. Bobroff

Associate Professor

Extension Foods and Nutrition Specialist

Julie Copenhagen

Graduate Student

Food Science and Human Nutrition

Older Infant/Toddlers and Young

Children Nutrition

Glenda L. Warren

Associate Professor

Extension Nutritionist, EFNEP

\section{Managing Resources}

Jeanette Davis

Interim, Extension Family and

Consumer Economics Specialist

Clothing for Mom/Baby Nutrition

R. Nadine Hackler

Professor

Extension Clothing Specialist

Consumer Choices/Safety

Mary Harrison

Professor, Extension Consumer

Education Specialist

Parenting

Joe Pergola

Extension Agent IV

Family Life

\section{Editor}

Linda D. Cook

Associate Professor

EFNEP Coordinator 


\section{CHOICES: Charting A Positive Future F or T een Parents}

\section{A T een Parent Curriculum}

The CHOICES curriculum is designed to help pregnant and parenting teens chart a more positive future. The curriculum recognizes that teens are still developing and have needs in addition to those of becoming a parent. The issues addressed include:

! Access to adequate prenatal care

! Reduction in the number of low birth weight babies

! Improved parenting skills

! Adequate nutrition/food for the mother, fetus and baby

! Resource management to become independent members of society

! Adequate confidence and skills to return to school or enter the work place

The Florida CHOICES curriculum has four units with several sub-sections:

FOCUS ON TEENS - Self-Esteem, Coping Skills, and Charting Your Future

NUTRITION - Maternal/Infant, and Adolescent/Young Child

RESOURCE MANAGEMENT - Managing resources, Clothing for Mom and and Consumer Choices/Safety

\section{PARENTING}

The CHOICES curriculum is a three-year project which is defined in the Scope and Sequences at the end of this Introduction section. This curriculum is inter-disciplinary and focuses on a broad range of teen parent needs. It has been designed to be experimental in that there are multiple learning activities for each concept. Each activity allows participant to DO-REFLECT-APPLY. CHOICES is flexible in that the leader can select the activities based on participants' needs, interests and resources. The curriculum is evolving and will continually be evaluated and redefined as the needs of pregnant and parenting teens change. 


\section{TABLE OF CONTENTS \\ Volume II}

\section{INTRODUCTION}

\section{Credits}

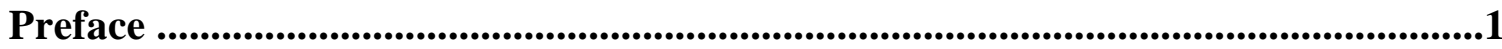

Table of Contents.......................................................................................................................2-6

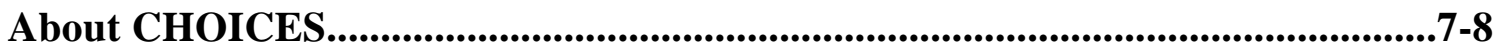

Three Year Scope and Sequence

FOCUS on Teens

Nutrition

Resource Management

Parenting

\section{CHOICES}

\section{Focus on Teens}

\section{Lesson 1: $\quad$ Self Esteem}

Teaching Outline

Background Basics ……................................................................ L1-3

Activities

1. I AM...I Can! ................................................................. L1-6

2. Positive Thoughts ............................................................ L1-9

3. You, First -Others, Second …………………………......... L1-12

4. Living With Choices ……………………………................... L1-14

\section{Lesson 2: Coping Skills}

Teaching Outline …….................................................................... L2-1

Background Basics .................................................................... L2-3

Activities

1. Know Your Stress ............................................................ L2-8

2. Warning Signals! …………………………………............. L2-10

3. Choices and Changes ....................................................... L2-12

4. The Pie of Life …………………………………......... L2-14

\section{Lesson 3: Charting Your Future}

Teaching Outline ……............................................................... L3-1

Background Basics ......................................................................... L3-3

Activities

1. The Power of Choice! ....................................... L3-7

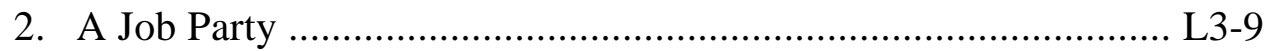

3. Package Your Talents .......................................................... 3-12

4. Application for Employment ………………………................. L3-14 


\section{Nutrition: Maternal}

\section{Lesson 1: Snack Attack}

Teaching Outline

Background Basics

Activities

1. Tasty Treats ................................................................... L1-5

2. Nutrition for A Buck ..................................................... L1-7

\section{Lesson 2: $\quad$ Fast Food Choices}

Teaching Outline

Background Basics

Activities

1. Fast and Healthy

2. Grab N' Go

\section{Lesson 3: Shaping Up}

Teaching Outline

Background Basics

Activities

1. Working Out With Baby

2. Talking With Tamara

\section{Resource Management: Managing Resources}

\section{Lesson 1: Cost of Having and Raising A Child}

Teaching Outline

Background Basics

Activities

1. Financial and Human Costs

$$
\text { of Having A Child }
$$

2. Cost of Raising A Child

\section{Lesson 2: Housekeeping}

Teaching Outline

Background Basics

Activities

1. What is Clean?

2. Identify Cleaning Tools

3. Cleaning Products 


\section{Resource Management: Clothing for Children}

Lesson 1: Selecting Toddler/Preschool Clothing

Teaching Outline

Background Basics

Activities

1. Buy By Size, Not Age

L1-7

2. Clothes That Grow and Are Safe

L1-10

3. I've Got Feelings

L1-12

4. I Can Dress Myself

\section{Lesson 2: Save on Toddler/Preschool Clothing}

Teaching Outline

Background Basics

Activities

1. Let's Go Shopping ……….......................................... L2-8

2. Measure to Fit ............................................................. L2-15

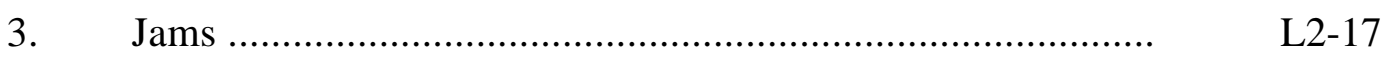

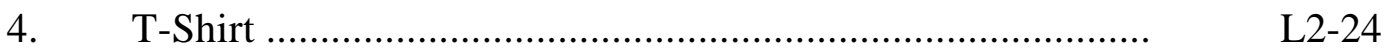

\section{Lesson 3: Caring for Toddler/Preschool Clothing}

Teaching Outline

Background Basics

Activities

1. Dissolve Detergent

2. To Bleach or Not To Bleach ......

3. Go Sort Card Game

4. Be Gone Spot

5. Clothing Care Road Signals

\section{Lesson 4: Garment Labeling}

Teaching Outline

Background Basics

Activities

1. Sorting Labels

2. Country of Origin

3. Label Of Fortune

\section{Lesson 5: Shopping For Children's Shoes}

Teaching Outline

Background Basics

Activities

1. How to Select Shoes

2. Heel to Toe 


\section{Resource Management: Consumer Choices/Safety}

\section{Lesson 1: Toy Safety}

Teaching Outline

Background Basics

Activities

1. Role of Toys

L1-6

2. Toy Selection

\section{Lesson 2: Consumer Education}

Teaching Outline

Background Basics

Activities

1. Deciding What To Buy

2. Where and When To Buy

3. Comparison Shopping

4. Deciding How To Pay......

\section{Parenting/Child Development}

\section{Lesson 1: Childrearing in the First Year}

Teaching Outline

Background Basics

Activities

1. Responding to Baby's Cries

2. Parenting Styles

\section{Lesson 2: Developmental Activities}

Teaching Outline

Background Basics

Activities

1. Parents and Infants Interaction

2. Using Developmental Activities

\section{Lesson 3: Coping Strategies for Parents}

Teaching Online

Background Basics

Activities

1. Pat on The Back

L3-4

2. Stress Relievers

\section{Resources}

Loan Kits

Fact Sheets

\section{Evaluation}




\section{About CHOICES}

The development of this CHOICES curriculum was driven by two basic principles:

1. Learning should be experiential and fun! The curriculum guide provides practical and real life activities to assist teens in their adjustments as pregnant teens and parents.

2. 4-H volunteer teaching activities must be ready-to-use. This curriculum includes reference materials and activity sheets needed to conduct educational activities in an easy-to-use format. It was designed to be teacher/leader friendly and takes much of the guesswork out of teaching the subject matter.

\section{Age OR Grade LeVels}

This curriculum was developed for pregnant and parenting teens, ages 13-15. However selected activities might be useable at other ages based on the development of the individual. Both group and individual activities encourage participation and action in all aspects of education. Teachers and volunteers are encouraged to select learning activities that are most suitable to their group. The overall intent is to facilitate learning and to spark creativity in both teachers and youth.

\section{CONTENTS}

The following are components of CHOICES curriculum:

C LEADER'S GUIDE - This three-ring notebook contains a complete, easy-to-read outline for lessons. Each lesson provides a variety of activities that can be conducted depending upon the time frame devoted to this curriculum. Each lesson is prefaced with a lesson outline including "Background Basics" to help you focus on the overall concepts and desired outcomes. Each lesson concludes with discussion questions for youth to "Reflect" and "Apply."

C CHOICES ACTIVITIES - self-inventories, field trips, and check sheets are just a few of the activities found in the leader's guide.

C TAKE HOME ACTIVITIES - additional activities designed to involve the teen's family and/or significant other in the learning and development. Activities such as "Parent's Attitudes", "Checking My Layette" and others allow teens to investigate their preparation and decisions regarding the baby and parenting; and check their attitudes and feelings with other care givers. 
C LOAN KITS, FACT SHEETS - additional resources to make learning more fun and interesting are identified in the Resources Section. Pertinent fact sheets to expand the "Background Basics" are also in the Resources Section.

C AUDIO VISUAL RESOURCES - such as videos and slide sets along with ordering information are identified in the Resources Section. 